\title{
CURRENT CONCERNS - USTR REPORT AND BIODIVERSITY GUIDELINES
}

\section{Dear Reader,}

The Indian Pharmaceutical Industry is considered globally as the prime source of high-quality generic medicines which are affordable, accessible and available to all countries irrespective of their geographical location or social and economic status. While India has established its leadership in generic medicines in USA and other developed, developing and least developed economies, we are still falling short in innovation and new drug research. There are events and news emanating from overseas as well as from domestic agencies which need our attention, response and needful action, in this context.

One such development is the USTR's (United States Trade Representative)

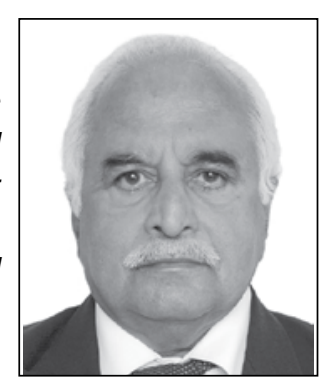
Annual Report for 2019 released in mid-April 2019. Once again, India finds its place in the "Priority Watch List", for IPR and Regulatory issues, most of which are routine. The 2018 \& 2019 Reports have expressed appreciation and positive comments for improvements undertaken by India in policies and actions. However, the old and stale "negative comments" such as on CL (Compulsory Licence), Sec.3(d) (patentability criteria), protection against unfair commercial use (data exclusivity) and unauthorized disclosure (for marketing approval), appear in the 2019 Report, as well.

However, the most surprisingly shocking statement in the 2019 Report relates to "counterfeit medicines". The Report states that $55 \%$ of global seizures of counterfeit pharmaceuticals by total value originated in India, shipped around the globe with special focus on Africa, Europe and USA. India needs to act rather than react, to this wrong statement and perception and further challenge the patently erroneous finding.

USA and EU, in particular, as also other countries, have the strictest regulatory agencies that allow imports of APIs and medicines into their countries only after thorough scrutiny. Hence this statement is not only unsubstantiable, false, derogatory but also defamatory. India is the prime source of high-quality APIs (bulk drugs) and generic medicines. India is the largest exporter of generic medicines to USA. India has the largest USFDA approved manufacturing sites both for APIs as well as formulations. India has the largest number of DMFs and ANDAs in USA.

The use of the term "counterfeit" by USTR is probably referring to generic equivalents of Patented and Off-patent medicines of the innovator. Ever since 1999, there has been extensive discussions on what is a counterfeit medicine. After considerable debate, including contributions from India and also eliciting views of IDMA, the definition of counterfeit was amended by WHO excluding Patent infringement and Intellectual Property elements except wilful misbranding. The term "counterfeit" has been proposed to be amended to SSFFC (Substandard/Spurious/Falsely-labelled/Falsified/Counterfeit). However, in 2017 the WHO has officially approved to use the definition "Substandard and falsified medical products" to substitute for use of the broader and erroneous term of counterfeit. WHO has further defined "Falsified medical products" as that which deliberately/fraudulently misrepresent their identity, composition or source.

In 2009, India has faced problems of seizure of "in transit" generic medicines in European ports/airports, alleging these to be counterfeit, only because they are generic equivalents of patented medicines, for export to countries where there are no patents on these medicines. India had taken prompt initiative and made a strong and effective response to the European Union as well as to USA to get the "counterfeit" claims squashed for "in transit" medicines. India needs to now respond strongly to USTR on their false allegation that $55 \%$ of global seizure of counterfeit pharmaceuticals originated in India to markets such as Africa, Europe and USA.

WHO's Global Surveillance and Monitoring System for substandard and falsified medical products (GSMS), in an extensive study conducted between 2013-17, had found that only $2 \%$ of the medical products in Southeast Asia, including India, were spurious against a global figure of 10.5\%, It defines falsified medical products as those that misrepresent identity, composition or source. US and EU were found to have $21 \%$ each of such products. 
The USTR Report repeats their old and stale allegations on CL (Compulsory Licence) even though the one and only CL was issued by India in 2012. Section 3(d) of Patents Act, 1970 and other patentability criteria in India are in place since 2005 or earlier. These have stood the test of time and has also been adopted globally in jurisprudence, even in USA. All negative comments in the 2019 Reports are routine and nothing new. The 2019 Report has complemented India for many positive initiatives on the IPR front.

It appears that USTR is facing a "Hobson's Choice". Having placed India in the "Priority Watch List" for years, find itself stuck, in spite of major reforms as well as strong initiatives in policy and procedures. At the same time, USTR finds itself helpless to remove India from the Priority Watch List, since there are few minor irritants in their declaration as such. When WTO and TRIPs as well as DSB (Dispute Settlement Body) under these treaties are in place, USTR will need to discontinue the Super 301 practices of Watch List and Priority Watch List which are violative of WTO rules.

A day is not too far when India may need to point out to USA, for being not in line with globally harmonised rules and regulations. "Outcome of the WTO Ministerial Meeting of Developing Countries - Working collectively to strengthening the WTO to promote development and inclusivity" (reproduced in the latest IDMA Bulletin), further strengthens the view that Super 301 Watch List is not in accordance with multilateral agreements on IPR such as TRIPS \& WTO.

Another area of concern for Indian Pharmaceutical Researchers and Manufacturers is the (Indian) Biodiversity Act, 2002 and Rules 2004. In April 2019, a revised guideline has been issued by the National Biodiversity Authority, which needs attention and deliberations. Response and comments are to be filed with the NBA before $24^{\text {th }}$ May 2019 (IDMA has already asked for extension of time by one month). In light of many reports that research in Indian Natural Products and bioresources are adversely impacted as a result of the tight and impractical controls by NBA and State Boards, it is strongly recommended that Indian research community and manufacturers come up with their views and alternate proposals in the best interest of $R \& D$ in Natural product-based pharmaceuticals.

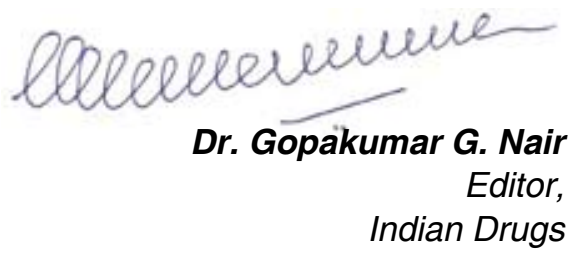

https://doi.org/10.53879/id.56.05.p0005 Indian Drugs

\section{About the Editor}

Dr. Gopakumar G. Nair is a Ph.D in Organic Chemistry (1966) from National Chemical Laboratory, Pune (Pune University). He was a Post-Doctoral fellow at IIT Bombay, Powai (1967) before joining the Pharma Industry. He was Director of Bombay Drug House P. Ltd., later Chairman of BDH Industries Ltd. as well as CMD of Bombay Drugs \& Pharma Ltd., which was merged with Strides Arcolab Ltd. in 2001. Dr. Nair served IDMA as office bearer for many years from 1972 onwards and was Chairman of various Committees for nearly 4 decades. He was the President of IDMA in 1999/2000. Currently, Dr. Nair is the Chairman of the IPR Committee in IDMA.

Having moved into the Intellectual Property field, he was the Dean of IIPS (Institute of Intellectual Property Studies) at Hyderabad in 2001/2002. Later, he set up his own boutique IP firm, Gopakumar Nair Associates, as well as Gnanlex Hermeneutics Pvt. Ltd., having done his L. L. B. from Mumbai University. He is also CEO of Patent Gurukul and President of Bharat Education Society, Kurla, Mumbai, managing many educational institutions in and around Mumbai.

प1

If you would like to comment on the editorial please write to us at publications@idmaindia.com 